Full Research Paper

\title{
Enhancement of BSA Binding on Au Surfaces by calix[4]bisazacrown Monolayer
}

\author{
Hongxia Chen ${ }^{1}$, Youn Sook Kim ${ }^{2}$, Jaebeom Lee ${ }^{2}$, Seok Ju Yoon ${ }^{3}$, Dong Seob Lim ${ }^{3}$, Heung-Jin \\ $\mathrm{Choi}^{3}$ and Kwangnak Koh ${ }^{2, *}$
}

1 College of Pharmacy, Pusan National University, Pusan 609-735, Korea

2 College of Nanoscience and Nanotechnology, Pusan National University, Pusan 609-735, Korea.

3 College of Engineering, Kyungpook National University, Taegu 702-701, Korea

* Author to whom correspondence should be addressed. E-mail: koh@pusan.ac.kr

Received: 21 September 2007 / Accepted: 10 October 2007 / Published: 11 October 2007

\begin{abstract}
Effective investigation of biomolecular structure and function with chip-based modern instruments often requires reliable and steady attachment of designated biomolecules on substrate. Here, we investigated the formation of self-assembled monolayer (SAM) with a new calix[4] arene derivative containing bisazacrown ether at the lower rim (calix[4]bisazacrown) where ammonium moieties of proteins can mainly be interacted with. Immobilization process of protein using bovine serum albumin (BSA) on the Au surface modified with calix[4]bisazacrown monolyer as an artificial linker system was monitored by surface plasmon resonance (SPR) technique. The surface concentration of BSA calculated by the simulation of SPR experimental data was higher than that of a well-known similar commercial protein linker. These results can help in modeling and understanding of protein immobilization on solid surface as well as further development lab-on-a-chip (LOC) devices for biomedical diagnosis kit of certain protein related diseases as biomarkers.
\end{abstract}

Keywords: Azacrown ether; Self-assembled monolayer (SAM); Linker system; Bovine serum albumin (BSA); Biochip.

\section{Introduction}

Protein adsorption on the surface of a foreign material is the initial event for the diverse applications such as advanced biosensors, biochips, bioreactors and many diagnostic techniques. It is 
quite significant to construct a well-characterized linker system that can efficiently immobilize proteins [1]. Calix[4]arene, which has a particular structure of lower or upper rims can be modified to achieve more sophisticated structures to bind specific guest molecules than normal receptors [2]. ProLinker $^{\mathrm{TM}}$ is a well-known calixarene derivative protein linker that has been utilized for guanidinium, antibody, enzyme and membrane receptor's immobilization [3-7]. ProLinker ${ }^{\mathrm{TM}}$ has a unique surface chemistry, which forms a self-assembled monolayer (SAM) on the gold surface and allows tight binding of capture proteins to the crown moiety of the linker molecules. The major binding force could be attributed to the ionized amine groups of capture proteins, which bind to the crown moiety of the linker molecule via host-guest interactions. Also, hydrophobic interactions between hydrophobic residues of a protein and methoxy groups of the calix[4]crown ether molecule may also be involved in protein immobilization. It preserves the random orientation of capture proteins, keeps the native composition of proteins and improves the accessibility for interaction proteins.

Azacrown ether same as crown ether has been used in the synthesis of artificial receptors for cations, anions and neutral organic molecules [8-11]. The nitrogen in the azacrown ring instead of the oxygen in the crown ring has free electron pairs that may be involved in stronger hydrogen binding with the ammonium ion moieties of protein than that of crown ether. Based on above, calix[4]arene azacrown derivatives are expected to be an artificial linker molecule system for protein immobilization. However, studies dealing with the immobilization of protein on the azacrown ether derivatives are quite sparse. In this study, a calix[4]arene bisazacrown derivative was synthesized with a upper rim of thiol group and two aza-18-crown-6 groups in the lower rim. In order to construct a well-characterized linker layer, calix[4]arene bisazacrown was self-assembly immobilized on gold surface. The linker monolayer formation process was investigated with SPR spectroscopy. For the application to protein linker, BSA as a standard protein was immobilized on the calix[4]bisazacrown linker system. The surface concentration of BSA was calculated, which was found to be comparable with that of a commercial protein linker (ProLinker ${ }^{\mathrm{TM}}$ ).

\section{Experimental}

\subsection{Materials}

BSA (B-4287, for molecular biology) and phosphate-buffered saline (PBS) were obtained from Sigma Chemical Co. (St. Louis, MO, USA). Tetrabenzylammonium chloride ( $>99 \%)$ and tetrmethylammonium chloride ( $>99 \%$ ) used for NMR were bought from Fluka Chemical Co. All other reagents were purchased from Aldrich Chemical Co. (Milwaukee, WI, USA). The molecular structures of calix[4]bisazacrown and ProLinker ${ }^{\mathrm{TM}}$ were shown in Figure 1. ProLinker ${ }^{\mathrm{TM}}$ was obtained from Proteogen Co. (Seoul, Korea). A Milli-Q grade $(>18.2 \mathrm{~m} \Omega \cdot \mathrm{cm})$ water was used for the preparation of buffer solutions.

\subsection{Synthesis and characterization of calix[4]bisazacrown}

The calix[4]bisazacrown was synthesized based on the procedures of the following literatures [12, 13]. The synthetic scheme was shown in Figure 1. Two aza-18-crown-6 were synthesized on the lower 
rim of calix[4]arene to bind with the ammonium ions of proteins. The thiol group on the upper rim is for the self-assembly immobilization on the gold surface.

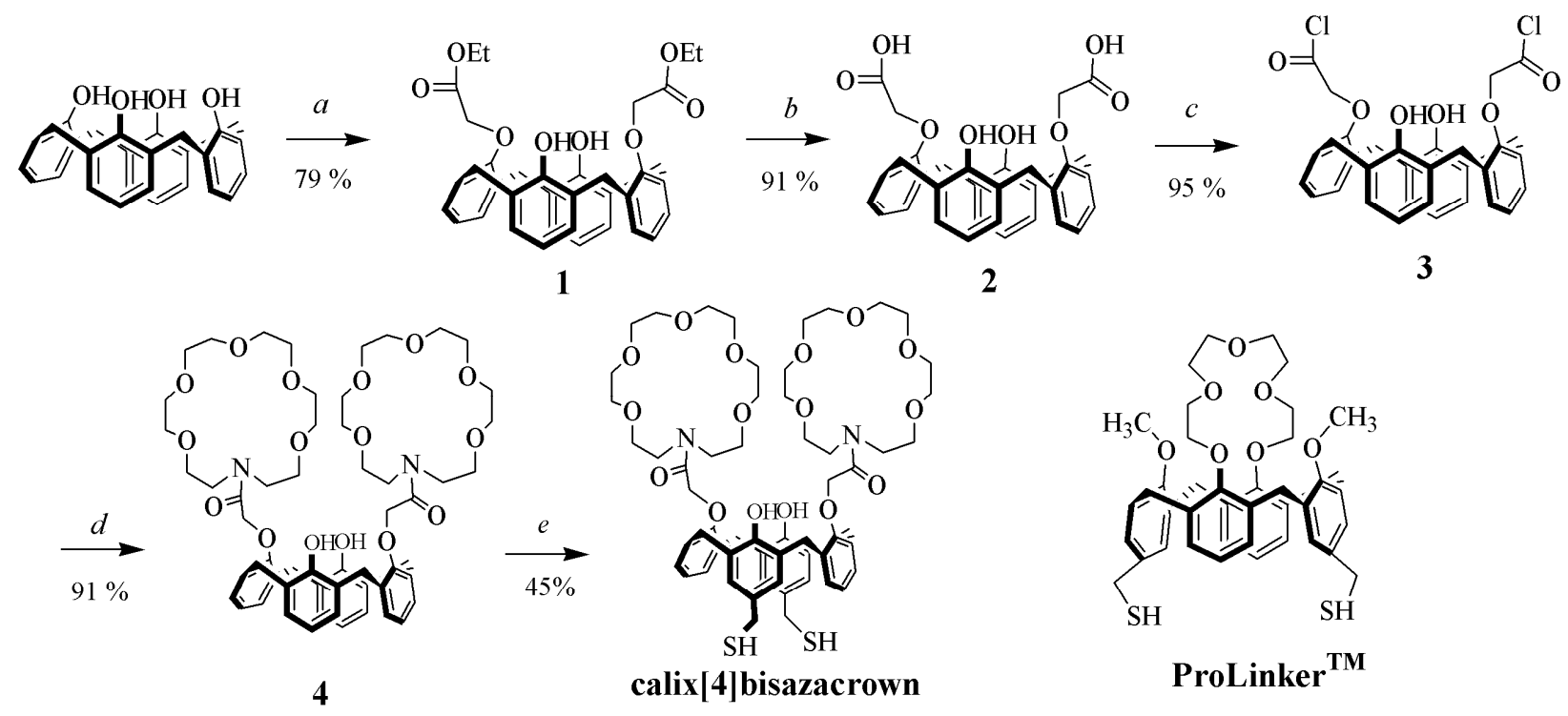

Reagents and Conditions: (a) $\mathrm{K}_{2} \mathrm{CO}_{3}$, acetonitrile, reflux, $24 \mathrm{~h}$;

(b) $\left(\mathrm{CH}_{3}\right)_{4} \mathrm{NOH}$, THF; (c) (1) $(\mathrm{COCl})_{2}, \mathrm{DMF},(2) \mathrm{THF}, 0^{\circ} \mathrm{C}$

(d) $\mathrm{NEt}_{3}, \mathrm{THF}$; (e) (1) $\mathrm{CH}_{3} \mathrm{OCH}_{2} \mathrm{Cl}, \mathrm{SnCl}_{4}, \mathrm{CH}_{2} \mathrm{Cl}_{2},-15^{\circ} \mathrm{C}, 3 \mathrm{~h}$;

(2) Thiourea, DMF, $3 \mathrm{~N}-\mathrm{NaOH}$; THF

Figure 1. Synthetic scheme of calix[4]bisazacrown and molecular structure of ProLinker ${ }^{\mathrm{TM}}$.

\subsubsection{Synthesis of 1}

A mixture of calix[4] arene $(1.7 \mathrm{~g}, 4 \mathrm{mmol}), \mathrm{K}_{2} \mathrm{CO}_{3}(0.68 \mathrm{~g}, 4.9 \mathrm{mmol})$ and ethyl bromoacetate $(1.40$ $\mathrm{g}, 8.4 \mathrm{mmol})$ was dissolved in $\mathrm{CH}_{3} \mathrm{CN}(200 \mathrm{~mL})$ and stirred for $24 \mathrm{~h}$ at room temperature. The solvent was completely removed by vacuum distillation. The residue was extracted with $\mathrm{CH}_{2} \mathrm{Cl}_{2}(20 \mathrm{~mL})$ and washed with deionized (DI) water for 3 times, followed drying with $\mathrm{MgSO}_{4}$ and evaporating the solvent. The product was recrystallized from $\mathrm{CH}_{2} \mathrm{Cl}_{2} / \mathrm{MeOH}(95: 5 \mathrm{v} / \mathrm{v})$ to afford white solid (3.25 g, $79 \%)$.

${ }^{1} \mathrm{H}$ NMR $\left(400 \mathrm{MHz}, \mathrm{CDCl}_{3}\right) \delta 7.04(\mathrm{~d}, \mathrm{~J}=7.5 \mathrm{~Hz}, \mathrm{Ar}-\mathrm{H}), 6.89(\mathrm{~d}, \mathrm{~J}=7.5 \mathrm{~Hz}, 4 \mathrm{H}, \mathrm{Ar}-\mathrm{H}), 6.72(\mathrm{t}, \mathrm{J}=$ $7.5 \mathrm{~Hz}, 2 \mathrm{H}, \mathrm{Ar}-\mathrm{H}$ ), 6.65 (t, J = 7.5 Hz, 2H, Ar-H), 4.72 (s, 4H, - $\left.\mathrm{OCH}_{2} \mathrm{CO}-\right), 4.48$ (d, J = $13.0 \mathrm{~Hz}, 4 \mathrm{H}$, $\left.\mathrm{CH}_{\mathrm{a}} \mathrm{H}_{\mathrm{b}}\right), 4.32\left(\mathrm{q}, \mathrm{J}=7.0 \mathrm{~Hz}, 4 \mathrm{H},-\mathrm{COCH}_{2} \mathrm{CH}_{3}\right), 3.39$ (d, J = 13.0 Hz, 4H, $\left.-\mathrm{CH}_{\mathrm{a}} \mathrm{CH}_{\mathrm{b}^{-}}\right), 1.34$ (t, J = 7.0 $\left.\mathrm{Hz}, 6 \mathrm{H},-\mathrm{COCH}_{2} \mathrm{CH}_{3}\right) 1.34\left(\mathrm{t}, \mathrm{J}=7.0 \mathrm{~Hz}, 6 \mathrm{H},-\mathrm{COCH}_{2} \mathrm{CH}_{3}\right) ;{ }^{13} \mathrm{C} \mathrm{NMR}\left(100 \mathrm{MHz}, \mathrm{CDCl}_{3}\right)$ $\delta 169.3,153.4,152.4,152.8,133.5,129.5,129.26,129.20,128.9,128.6,127.9,120.6,119.5,78.3,72$. $9,61.8,31.9,14.6$.

\subsubsection{Synthesis of $\mathbf{2}$}

A mixture of 1 (2.75 g, $4.6 \mathrm{mmol})$, THF ( $80 \mathrm{~mL})$, tetramethylammoniu hydroxide ( $25 \mathrm{wt} . \%$ solution in water, $40 \mathrm{~mL})$ and distilled water $(80 \mathrm{~mL})$ was stirred for $24 \mathrm{~h}$. The solvent was removed. The 
residue was extracted with $3 \mathrm{~N} \mathrm{HCl}$ and washed with $\mathrm{DI}$ water for 3 times, then, dried with $\mathrm{MgSO}_{4}$ in vacuum. White chunk powders were obtained (1.9 g, 91\%).

${ }^{1} \mathrm{H}$ NMR $\left(400 \mathrm{MHz}, \mathrm{CDCl}_{3}\right) \delta 7.11(\mathrm{~d}, \mathrm{~J}=7.5 \mathrm{~Hz}, 4 \mathrm{H}, \mathrm{Ar}-\mathrm{H}), 7.0(\mathrm{~d}, \mathrm{~J}=7.6 \mathrm{~Hz}, 4 \mathrm{H}, \mathrm{Ar}-\mathrm{H}), 6.76(\mathrm{t}$, $\mathrm{J}=7.6 \mathrm{HZ}, 2 \mathrm{H}, \mathrm{Ar}-\mathrm{H}), 4.70\left(\mathrm{~s}, 4 \mathrm{H},-\mathrm{OCH}_{2} \mathrm{CO}-\right), 4.38\left(\mathrm{~d}, \mathrm{~J}=13.0 \mathrm{~Hz}, 4 \mathrm{H},-\mathrm{CH}_{\mathrm{a}} \mathrm{H}_{\mathrm{b}}\right), 3.40$ (d, J = 13.0 $\left.\mathrm{Hz}, 4 \mathrm{H},-\mathrm{CH}_{\mathrm{a}} \mathrm{H}_{\mathrm{b}^{-}}\right) ;{ }^{13} \mathrm{C} \mathrm{NMR}\left(100 \mathrm{MHz}, \mathrm{CDCl}_{3}\right) \delta 170.8,153.2,152.8,133.8,129.3,128.9,128.2$, 125.4, 119.3, 72.7, 30.9.

\subsubsection{Synthesis of $\mathbf{3}$}

2 (134 mg, $0.25 \mathrm{mmol})$ in THF (10 mL) was dropped into oxalyl chloride (116 mg, $0.9 \mathrm{mmol})$ in DMF using ice-bath and stirred for $40 \mathrm{~min}$. Yellow solid was obtained after evaporating the solvent.

\subsubsection{Synthesis of 4}

1-aza-18-crown-6 ether (131 mg, $0.5 \mathrm{mmol})$ was dissolved in dehydrated THF ( $5 \mathrm{~mL})$ under $\mathrm{N}_{2}$, and then added to triethylamine $(80 \mu \mathrm{L})$. The mixture solution was reacted with 3 (144 $\mathrm{mg}, 0.25$ mmol) solved in dehydrated THF $(10 \mathrm{~mL})$ under $\mathrm{N}_{2}$ gentle stirring for $10 \mathrm{~min}$ at $0^{\circ} \mathrm{C}$ and 5 hours at room temperature. Then, the residue was filtered by Celite. The product was separated by silica gel column with $\mathrm{CH}_{2} \mathrm{Cl}_{2}: \mathrm{MeOH}(95: 5 \mathrm{v} / \mathrm{v})$ as an eluent. White solid powders $(224 \mathrm{mg}$, 91\%) were obtained after evaporation.

${ }^{1} \mathrm{H}$ NMR (400 MHz, $\left.\mathrm{CDCl}_{3}\right) \delta 8.04(\mathrm{~s}, 2 \mathrm{H}, \mathrm{Ar}-\mathrm{H}), 6.99(\mathrm{~d}, \mathrm{~J}=7.5 \mathrm{~Hz}, 4 \mathrm{H}, \mathrm{Ar}-\mathrm{H}), 6.88(\mathrm{t}, \mathrm{J}=$ $7.5 \mathrm{~Hz}, 4 \mathrm{H}, \mathrm{Ar}-\mathrm{H}$ ), $6.72(\mathrm{t}, \mathrm{J}=7.5 \mathrm{~Hz}, 2 \mathrm{H}, \mathrm{Ar}-\mathrm{H}), 6.58(\mathrm{t}, \mathrm{J}=7.6 \mathrm{~Hz}, 2 \mathrm{H}, \mathrm{Ar}-\mathrm{H}) 4.89$ (s, 4H, $\left.\mathrm{OCH}_{2} \mathrm{CO}-\right), 4.49$ (d, J = 13.1 Hz, $\left.4 \mathrm{H},-\mathrm{CH}_{\mathrm{a}} \mathrm{H}_{\mathrm{b}}\right), 3.79-3.73\left(\mathrm{~m}, 48 \mathrm{H},-\mathrm{OCH}_{2} \mathrm{CH}_{2} \mathrm{NCH}_{2} \mathrm{CH}_{2} \mathrm{O}-\right), 3.3(\mathrm{~d}, \mathrm{~J}=$ $\left.13.1 \mathrm{~Hz}, 4 \mathrm{H},-\mathrm{CH}_{\mathrm{a}} \mathrm{H}_{\mathrm{b}^{-}}\right) ;{ }^{13} \mathrm{C} \mathrm{NMR}\left(100 \mathrm{MHz}, \mathrm{CDCl}_{3}\right), \delta 168.3,153.5,153.1,133.6,128.9,128.3$, 128.2, 125.2, 118.8, 73.8, 71.1, 70.77, 70.75, 70.69, 70.65, 70.64, 70.5, 70.4, 69.8, 69.5, 48.6, 47.0, 31.6 .

\subsubsection{Synthesis of calix[4]bisazacrown}

$\mathrm{CHCl}_{3}(15 \mathrm{~mL})$ and chloromethyl methyl ether $(125 \mathrm{mg}, 1.55 \mathrm{mmol}, 0.12 \mathrm{~mL})$ were mixed under $\mathrm{N}_{2}$ gas purging in ice bath for $3 \mathrm{~min} .1 \mathrm{M}^{-\mathrm{SnCl}_{3}}$ (in $\mathrm{CH}_{2} \mathrm{Cl}_{2}, 0.78 \mathrm{~mL}, 0.78 \mathrm{mmol}$ ) was added and stirred for $15 \mathrm{~min}$. Then 4 (40 mg, $0.039 \mathrm{mmol})$ dissolved in $\mathrm{CHCl}_{3}(10 \mathrm{~mL})$ solution was added to the mixture solution, followed stirring in the ice bath for 1 hour and at room temperature for 3 hours. The organic layer was washed gently using DI water 2 times and dried out with $\mathrm{MgSO}_{4}$. The final powder was white colored using the same method as the previous method. Then, the white solid powder (20 $\mathrm{mg}, 0.018 \mathrm{mmol}$ ) and thiourea $\left(8 \mathrm{mg}, 0.1 \mathrm{mmol}\right.$ ) was mixed under non-/oxigen state with $\mathrm{N}_{2}$ gas purging. The sample in DMF $(7 \mathrm{~mL})$ was stirred for $12 \mathrm{~h}$. The solvent was removed and dried with $\mathrm{MgSO}_{4}$. Then THF $(10 \mathrm{~mL})$ and $3 \mathrm{~N} \mathrm{NaOH}(0.5 \mathrm{~mL})$ and DI water $(5 \mathrm{~mL})$ were added in series and stirred for $10 \mathrm{~min} . \mathrm{CH}_{2} \mathrm{Cl}_{2}(5 \mathrm{~mL}), \mathrm{NH}_{4} \mathrm{Cl}(10 \mathrm{~mL})$ and $\mathrm{NaBH}_{4}(80 \mathrm{mg})$ were added to the residue after evaporating the solvent. The organic layer was washed out by DI water and dried by $\mathrm{MgSO}_{4}$. Yellow solid aggregates were obtained after removing the solvent (18 $\mathrm{mg}, 45 \%)$.

${ }^{1} \mathrm{H}$ NMR $\left(400 \mathrm{MHz}, \mathrm{CDCl}_{3}\right) \delta 6.90(\mathrm{~s}, 4 \mathrm{H}, \mathrm{Ar}-\mathrm{H}), 6.81(\mathrm{~d}, \mathrm{~J}=7.5 \mathrm{~Hz}, 4 \mathrm{H}, \mathrm{Ar}-\mathrm{H}), 6.65(\mathrm{t}, \mathrm{J}=$ 7.5Hz, 2H, Ar-H ), 4.82 (s, 4H, $\left.-\mathrm{OCH}_{2} \mathrm{CO}-\right), 4.40$ (d, J = 13.0 Hz, 4H, - $\left.\mathrm{CH}_{\mathrm{a}} \mathrm{H}_{\mathrm{b}}\right), 4.22\left(\mathrm{~s}, 4 \mathrm{H},-\mathrm{CH}_{2} \mathrm{SH}\right)$, 
3.71-3.53 (m, 48H, $\left.-\mathrm{OCH}_{2} \mathrm{CH}_{2} \mathrm{NCH}_{2} \mathrm{CH}_{2} \mathrm{O}-\right), 3.26\left(\mathrm{~d}, \mathrm{~J}=13.0 \mathrm{~Hz}, 4 \mathrm{H},-\mathrm{CH}_{\mathrm{a}} \mathrm{H}_{\mathrm{b}^{-}}\right) ;{ }^{13} \mathrm{C} \mathrm{NMR}(100$ $\left.\mathrm{MHz}, \mathrm{CDCl}_{3}\right) \delta 167.6,152.4,151.7,132.4,127.9,127.3,127.0,124.5,124.2,73.7,72.7,70.0,69.7$, $69.64,69.58,69.44,69.3,68.7,68.5,56.6,47.5,45.9,30.6,24.6$.

\subsection{Formation of calix[4]azacrown and ProLinker ${ }^{T M}$ SAMS}

A gold chip ( $2 \mathrm{~nm}$ chromium adhesion layer and $45 \mathrm{~nm}$ of gold) constructed of one body with a prism $(18 \times 18 \mathrm{~mm})$ was purchased from K-MAC (Daejeon, Korea). The bare gold chip surface was carefully rinsed with methanol and swelled in a mixed solution $\left(\mathrm{CHCl}_{3}: \mathrm{MeOH}=1: 199(\mathrm{v} / \mathrm{v})\right)$. ProLinker $^{\mathrm{TM}}$ and calix[4]bisazacrown were prepared to $0.1 \mathrm{mM}$ of the mixed solution $\left(\mathrm{CHCl}_{3}: \mathrm{MeOH}\right.$ $=1: 199(\mathrm{v} / \mathrm{v}))$ for the SAM formation on gold surface. The SAMs were formed by flow two solutions through two gold chips for about $5 \mathrm{~h}$ with a flow rate of $5 \mu \mathrm{L} / \mathrm{min}$ separately. The immobilization process was monitored by SPR spectroscopy. After the immobilization process, the sensor chip was sequentially rinsed with mixed solution, methanol and DI water.

\subsection{BSA immobilization and surface concentration calculation}

BSA was used as a standard protein to observe the protein immobilization on the artificial linker layers and theoretical calculation. The concentration of BSA solution for protein immobilization was 5 $\mathrm{M}$ in phosphate buffer (0.01 M, pH 7.4). The immobilization process of BSA was measured by SPR. The surface concentration of immobilized BSA was calculated according to the following equation (eq. 1) [13].

$$
\Gamma=3 d\left(n^{2}-n_{b}^{2}\right) /\left[\left(n^{2}+2\right)\left(r\left(n_{b}^{2}+2\right)-v\left(n_{b}^{2}-1\right)\right)\right]
$$

where, $\Gamma$ and $d$ are the surface concentration of adsorbed molecules and the thickness of adsorbed layer, respectively. $\mathrm{nb}$ and $\mathrm{n}$ are the refractive index of the buffer solution and the adsorbed layer, respectively. $r$ and $v$ are the specific refractivity of BSA $(0.243 \mathrm{ml} / \mathrm{g})$ and the partial specific volume of BSA $(0.729 \mathrm{ml} / \mathrm{g})$ deposited on the linker layer.

The optical parameters were determined by the simulation from the experimental SPR data. They were required for the calculation of the surface concentration of immobilized BSA and SAMs [4]. In order to determine optical constant of each layer theoretically, the four-layer model was applied to our study.

\subsection{SPR spectroscopic measurement}

SPR spectroscopic measurements for the monolayer formation of ProLinker ${ }^{\mathrm{TM}}$ and calix[4]bisazacrown SAMs and BSA immobilization were measured by commercial SPR system (KMAC Co., SPR Lab, Daejeon, Korea). SPR measurements were performed at $25^{\circ} \mathrm{C}( \pm 0.1)$ with the resolution of $0.01^{\circ}$. A schematic diagram of sensor chip configuration is shown in Figure 2. 


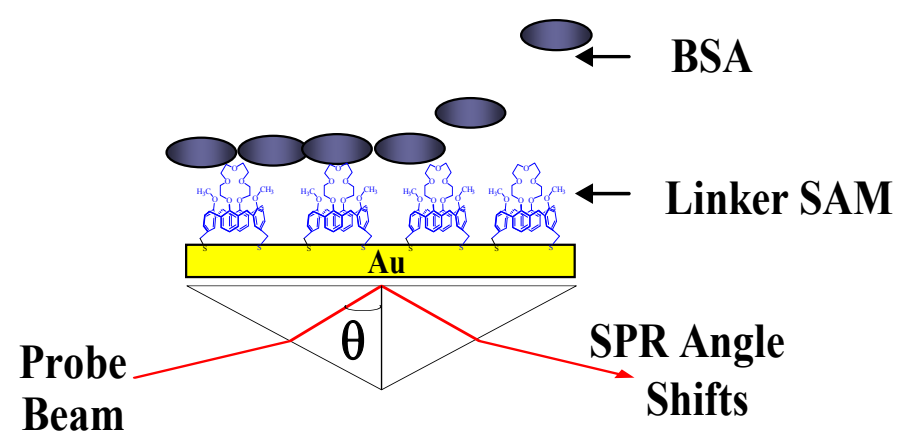

Figure 2. Schematic diagram of BSA immobilization on the calixarene monolayer.

\section{Results and Discussion}

\subsection{Formation of SAMs.}

In the immobilization process, as the number of immobilized molecule increasing, the SPR angle shifted to higher angle and saturated at inner $5 \mathrm{~h}$ for both of SAMs as shown in Figure 3. SPR angle shifts $(\Delta \theta)$ that caused by the fabrication of SAMs were $0.08^{\circ}$ (ProLinker $^{\mathrm{TM}}$ ), $0.17^{\circ}$ (Calix[4]bisazacrown) respectively. Both SPR simulation results showed the calix[4]bisazacrown has bigger $d$ and $n$ value than that of ProLinker ${ }^{\mathrm{TM}}$, which may contribute to the big SPR angle shift of calix[4]bisazacrown SAM (Table 1).

Table 1. Surface concentration of the immobilized BSA, SAMs and optical parameters determined by theoretical simulation.

\begin{tabular}{|c|c|c|c|c|c|c|c|c|c|c|}
\hline \multirow{2}{*}{ Monolayer } & \multicolumn{3}{|c|}{ Bare gold } & \multicolumn{3}{|c|}{ Linker Layer } & \multicolumn{3}{|c|}{ BSA Layer } & \multirow{2}{*}{ 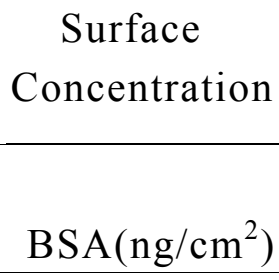 } \\
\hline & $n$ & $k$ & $d$ & $n$ & $k$ & $d$ & $n$ & $k$ & $d$ & \\
\hline ProLinker $^{\mathrm{TM}}$ & 0.21 & 3.68 & 47.5 & 1.59 & 0.08 & 1.3 & 1.57 & 0.7 & 1.33 & 175 \\
\hline calix[4]bisazacrown & 0.21 & 3.68 & 47.5 & 1.60 & 0.07 & 1.8 & 1.57 & 0.7 & 1.5 & 197 \\
\hline
\end{tabular}

$n, k$ and $d$ denote refractive index, extinction coefficient, geometrical thickness (nm) respectively.

\subsection{BSA immobilization on the SAMs}

Crown ethers have been studied extensively due to their ability to bind metal cations. The ability of crown ethers, particularly 18-crown-6 (18C6), to complex with ammonium or alkylammonium ions in the gas phase has also been demonstrated $[14,15]$. Protein was immobilized on the crown ether layer via host-guest and hydrophobic interactions [3]. The nitrogen in the aza-18-crown-6 instead of the 
oxygen has free electron pairs that may be involved in strong hydrogen binding with the ammonium ion in the captured protein.

In the study of protein immobilization process using BSA, as the adsorbed BSA molecule increased on gold surface, SPR angle shifts were gradually increased and saturated at inner $2 \mathrm{~h}$ (Figure 3 ).

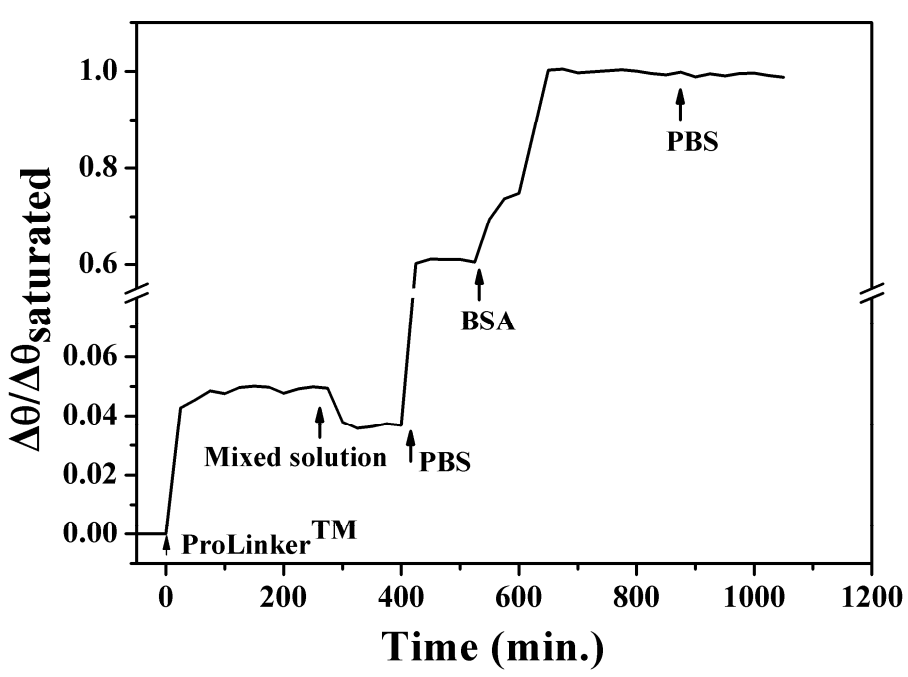

(a)

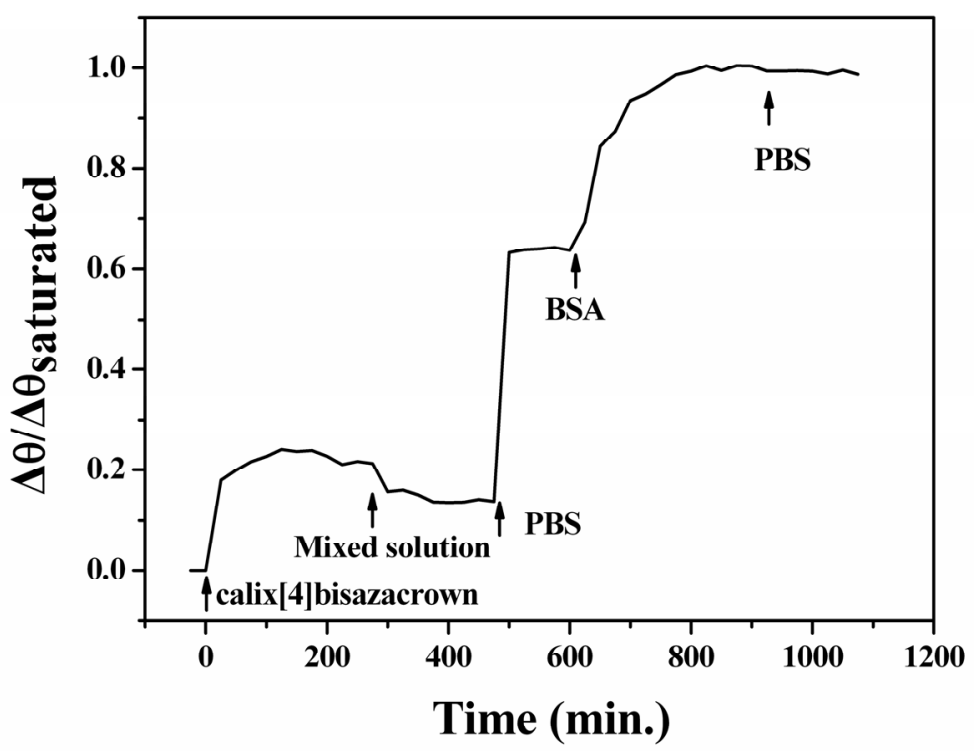

(b)

Figure 3. Kinetic sensogram the formation of calix[4]arene SAMs on Au surface and BSA immobilization on (a) ProLinker ${ }^{\mathrm{TM}}$ SAM and (b) calix[4] bisazacrown SAM.

To calculate the protein surface concentration, the optical parameters are required by simulation with experimental SPR data. Figure 4 showed the experimental and calculated SPR curves of ProLinker $^{\mathrm{TM}}$ and calix[4]bisazacrown SAMs according to the immobilization of BSA. The optical 
parameters of two SAMs were shown in Table 1. The calculated BSA surface concentrations are 175 $\mathrm{ng} / \mathrm{cm}^{2}$ (on ProLinker ${ }^{\mathrm{TM}} \mathrm{SAM}$ ) and $197 \mathrm{ng} / \mathrm{cm}^{2}$ (on calix[4]bisazacrown SAM) respectively.

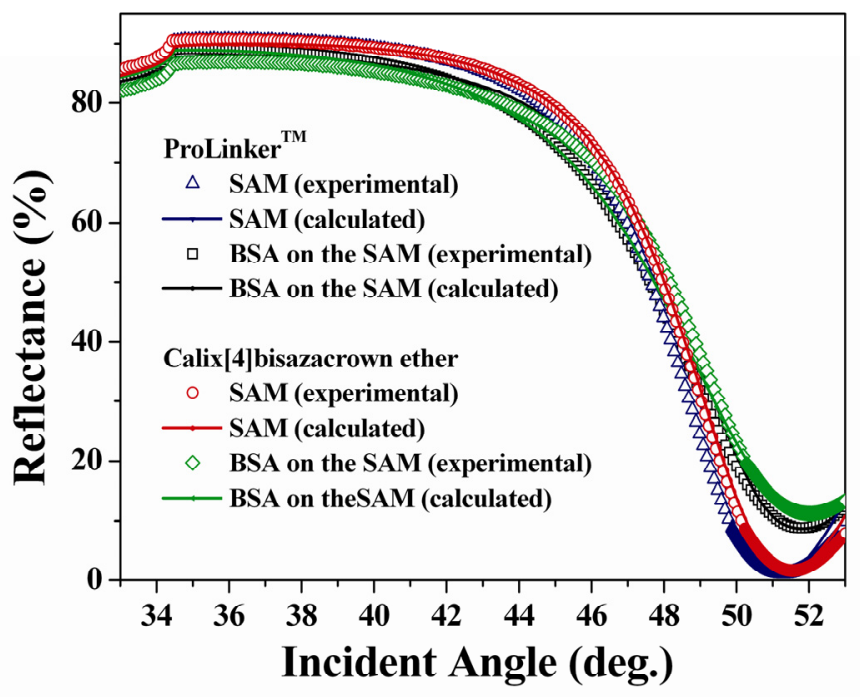

Figure 4. Experimental and simulated theoretical SPR curve corresponding to SAMs and BSA immobilization.

Although two SAMs were formed on the commonly deposited gold surface instead of on the gold (111) crystal, the surface concentration of immobilized BSA on the SAMs are similar to that of wellordered alkanethiol SAM on gold (111) surface [16], which indicates the immobilized BSA on these two SAMs is near well ordered monolayer state.

ProLinker $^{\mathrm{TM}}$ is a commercial protein linker and has been confirmed by many experiments [3-6]. BSA surface concentration on the ProLinker ${ }^{\mathrm{TM}} \mathrm{SAM}$ is $11 \%$ less than that of on the calix[4]bisazacrown SAM. It may result from 1) the calix[4]bisazacrown has two crown ether rings which afford more opportunities to interact with proteins; 2) the hydroxyl groups in calix[4]bisazacrown are substituted to the methoxy groups in ProLinker ${ }^{\mathrm{TM}}$. Therefore, the formation of hydrogen bonds between calix[4]bisazacrown and protein in hydrophobic pocket surrounded by great proteins boundary may induce stronger interactions; 3) the calix[4]bisazacrown rings have higher flexibility than one crown ether ring of ProLinker ${ }^{\mathrm{TM}}$, which may preserve the protein's native activity and contribute to increase the immobilized protein's binding efficiency [17]. Additionally, the nitrogen in the azacrown ring has free electron pairs which may also be involved in stronger hydrogen binding with the ammonium ion moieties of protein. These results indicate that calix[4]bisazacrown has practical advantage as a linker system for protein immobilization

\section{Conclusion}

In this study, calix[4]bisazacrown which contains azacrown rings at the lower rim with a common reactive thiol at the upper rim was constructed to monolayer on $\mathrm{Au}$ surface. Surface confined calix[4]bisazacrown has potential applications in the development of molecular linker layer for immobilizing protein by selective affinity at the surface. The interaction between BSA and surface 
confined calix[4]bisazacrown was compared with commercial protein linker system by SPR. The surface concentration of immobilized BSA was higher than that of commercial protein linker system. These results indicate that the bisazacrown as a functional group at the lower rim of calix[4]arene exert a critical effect on the stable affinity toward the protein onto the SAM. In conclusion, the main results of this research showed that the SPR technique and the novel well-designed calixarene derivative SAM are very useful to the development of more efficient biosensing interface through more efficient protein immobilization.

\section{Acknowledgements}

Author H.-J. Choi gratefully acknowledges the financial support of the research professor program of Kyungpook National University (2006).

\section{References and Notes}

1. Silin, V.; Weetall, H.; Vanderah, D.J. SPR Studies of the Nonspecific Adsorption Kinetics of Human IgG and BSA on Gold Surfaces Modified by Self-Assembled Monolayers (SAMs). $J$. Colloid Interface Sci. 1997, 185, 94-103.

2. Yilmaz, A.; Memon, S.; Yilmaz, M. Synthesis and study of allosteric effects on extraction behavior of novel calixarene-based dichromate anion receptors. Tetrahedron 2002, 58, 7735 7740 .

3. Lee, Y.; Lee, E. K.; Cho, Y. W.; Matsui, T.; Kang, I. C.; Kim, T. S.; Han, M. H. ProteoChip: a highly sensitive protein microarray prepared by a novel method of protein immobilization for application of protein-protein interaction studies. Proteomics 2003, 3, 2289-2304.

4. Chen, H; Lee, M.; Choi, S.; Kim, J. H.; Choi, H. J.; Kim, S. H.; Lee, J.; Koh, K. Comparative study of protein immobilization properties on calixarene monolayers. Sensors, 2007, 7, 10911107.

5. Sasakura, Y.; Kanda, K.; Suzuki, T. Y.; Matsui, T.; Fukuzono, S.; Han, M. H.; Shimizu, T. Protein Microarray System for Detecting Protein-Protein Interactions Using an Anti-His-Tag Antibody and Fluorescence Scanning: Effects of the Heme Redox State on Protein-Protein Interactions of Heme-Regulated Phosphodiesterase from Escherichia coli. Anal. Chem. 2004, $76,6521-6527$.

6. Lee, Y.; Kang, D. K.; Chang, S. I.; Han, M. H.; Kang, I. C. High-Throughput Screening of Novel Peptide Inhibitors of an integrin receptor from the hexapeptide library by using a protein microarray chip. Journal of Biomolecular Screening 2004, 9, 687-694.

7. Chen, H.; Kim, Y. S.; Keum, S. R.; Kim, S.-H.; Choi, H.-J.; Lee, J.; An, W. G.; Koh, K. Surface Plasmon Spectroscopic Detection of Saxitoxin. Sensors 2007, 7, 1216-1223.

8. Gawley, R. E.; Pinet, S.; Cardona, C. M.; Datta, P. K.; Ren, T.; Guida, W. C.; Nydick, J.; Leblanc, M. Chemosensors for the Marine Toxin Saxitoxin. J. Am. Chem. Soc. 2002, 124, 13448-13453.

9. Kim, J. S.; Shon, O. J.; Ko, J. W.; Cho, M. H.; Yu, I. Y.; Vicens, J. Synthesis and Metal Ion Complexation Studies of Proton-Ionizable Calix[4]azacrown Ethers in the 1,3-Alternate Conformation. J. Org. Chem. 2000, 65, 2386-2392. 
10. Kimura, K.; Mizutani, R.; Suzuki, T.; Yokoyama, M. Photochemical Ionic-Conductivity Switching Systems of Photochromic Crown Ethers for Information Technology J. Incl. Phenom. Macro. 1998, 32, 295-310.

11. Choi, H. J.; Kwak, M. O.; Kim, J. M. Tetrahedrally Arranged Tetraamide Macrocycle: Synthesis and Properties of L-Tartaric acid-based Macrocyclic Tetraamide. Tetra. Lett. 1997, $38,6217-6220$.

12. Iki, N.; Narumi, F.; Fujimoto, T.; Morohashi, N.; Miyano, S. Selective synthesis of three conformational isomers of tetrakis[(ethoxycarbonyl)methoxy]thiacalix[4]arene and their complexation properties towards alkali metal ions. J. Chem. Soc. Perkin Trans. 1998, 2, 2745 2750 .

13. Corsel, J. W.; Willems, G. M.; Kop, J. M. M.; Cuypers, P. A.; Hermens, W. T. The role of intrinsic binding rate and transport rate in the adsorption of prothrombin, albumin, and fibrinogen to phospholipid bilayers. J. Colloid Interface Sci. 1986, 111, 544-554.

14. Maleknia, S.; Brodbelt, J. S. Cavity-size-dependent dissociation of crown ether/ammonium ion complexes in the gas phase. J. Am. Chem. Soc. 1993, 115, 2837-3843.

15 Lee, S. -W.; Lee, H. -N.; Kim, H. S.; Beauchamp J. L. Selective Binding of Crown Ethers to Protonated Peptides Can Be Used to Probe Mechanisms of H/D Exchange Reactions and Collision-Induced Dissociation Reactions in the Gas Phase. J. Am. Chem. Soc. 1998, 120, 5800-5805.

16. Nonogaki, T.; Xu, S.; Kugimiya, S.; Sato, S.; Miyata, I.; Yonese, M. 2-Dimensional AutoOrganized Nanostructure Formation of Hyaluronate on Bovine Serum-Albumin Monolayer and Its Surface- Tension. Langmuir 2000, 16, 4272-4278.

17. Morozov, V.N. Protein Microarrays: Principles and Limitations. In Protein Microarrays, Schena, M., Ed; Jones and Bartlett Publishers: Boston, 2004; p 83.

C 2007 by MDPI (http://www.mdpi.org). Reproduction is permitted for noncommercial purposes. 